Revistade
Economida
Contemporâned

\title{
THE COST OF DIRECT TAXATION ON INVESTMENT IN BRAZIL
}

\author{
Nelson Leitão Paes ${ }^{a}$

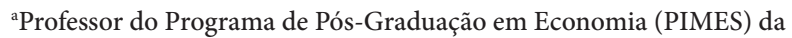 \\ Universidade Federal de Pernambuco (UFPE).
}

Artigo recebido em 04/05/2016 e aprovado em 30/05/2017.

\begin{abstract}
This paper analyzed the impact of taxation on the investment in Brazil, focusing on the taxation of corporate income. Following the literature, it was used an economic model to calculate two indicators of effective tax rates - Effective Marginal Tax Rate (EMTR) and Effective Average Tax Rate (EATR). The EMTR measures the increase of the cost of capital due to corporate income tax. The EATR represents a measure of the average tax rate levied on an investment that has a pre-defined economic profit. The results suggest Brazil may face some difficulties to attract foreign investment. The country presents high rates for EATR and EMTR, higher than the average of the rich countries and well above the figures of development countries like Chile, Mexico, South Africa, Russia and China, potential competitors in attracting investments.
\end{abstract}

KEYWORDS: effective rates; tax burden; comparative analysis.

JEL CODES: $\mathrm{H} 20 ; \mathrm{H} 22 ; \mathrm{H} 25$. 


\section{O CUSTO DA TRIBUTAÇÃO DIRETA SOBRE O INVESTIMENTO NO BRASIL}

RESUMO: Este artigo analisa o impacto da tributação no investimento para o Brasil, com atenção especial sobre a renda da pessoa jurídica. Seguindo a literatura sobre o tema, foi utilizado um modelo econômico para o cálculo de dois indicadores de alíquotas tributárias efetivas - EMTR (Effective Marginal Tax Rate) e EATR (Effective Average Tax Rate). O EMTR mede o aumento do custo do capital devido à tributação da renda da pessoa jurídica. Já o EATR representa uma medida da alíquota media que incide sobre um investimento que tem uma taxa de retorno pré-definida. Os resultados sugerem que o Brasil pode enfrentar algumas dificuldades para a tração de investimento estrangeiro. O país apresenta altas taxas para o EATR e o EMTR, mais elevada que a media dos países desenvolvidos e bem acima dos valores de países em desenvolvimento como Chile, México, África do Sul, Rússia e China, potenciais competidores na atração de investimentos.

PALAVRAS-CHAVE: alíquotas efetivas; carga tributária; análise comparativa. 


\section{INTRODUCTION}

Direct taxation on investments has been the subject of concerns and disputes between countries. Data from Organization for Economic Cooperation and Development (OECD, s/d) point to sharp declines in rates of corporate income tax in the last 25 years, as a way to attract investment.

In Brazil, however, when thinking about investment, companies always point out the high costs of indirect taxation, but not on direct taxes. This is because indirect taxes and contributions on investment in Brazil are only partly compensated. Recent work by the National Industry Confederation (CNI, 2014) on the tax cost of the investment comes to proposals to eliminate indirect taxes (ISS, ICMS, PIS, Cofins, IPI and AFRMM) ${ }^{1}$ on investment, but not say anything about direct taxes.

However, in most developed countries this discussion is already outdated. Indirect taxes such as the Value Added Tax are not levied on investment, or when it happens, it is quickly recovered. All the tax cost of the investment is related to direct taxation, such as the Income Tax.

This paper aims to analyze the tax cost of the investment in Brazil and its focuses on the taxation of corporate income. According to what the literature suggests, an economic model has been employed to calculate two indicators of effective rates - the Effective Marginal Tax Rate (EMTR) and the Effective Average Tax Rate (EATR).

The EMTR measures the increase in the cost of capital as a result of the taxation of corporate income. It is assumed that the investment will occur until the level where the marginal gain of an additional unit of investment equals the cost of capital. The tax increases the cost of capital and ultimately reduces investment. The EATR is a measure of the average effective tax rate on investment that has a predefined economic profit.

From the perspective of policymakers, the EATR could serve as an important indicator for choosing the location of a factory among several countries, while the EMTR is believed to be a relevant indicator for the level of investment that would be realized.

The results show that Brazil may face difficulties in attracting investments. The country has high rates of EATR and EMTR, higher than the average of OECD countries and above important developing countries such as Chile, Mexico, South Africa, Russia and China, which are potential competitors in terms of investment attraction.

\footnotetext{
ISS - Local Tax on Services; ICMS - Estate Tax on Goods; PIS - Federal Tax on Good and Services; COFINS - Also, a federal tax on goods and services; IPI - Excise tax on industrialized products; AFRMM - Tax on Maritime Freights.
} 
After this brief introduction, the following section presents a literature review, that highlights the models used to calculate the EMTR and EATR and the results already found. Section 3 develops the theoretical model used in this paper. Section 4 presents the main results and compares the figures for Brazil with those of a group of relevant countries. Finally, Section 5 concludes with suggestions for the Brazilian tax policy.

\section{LITERATURE REVIEW}

The development of indicators as a measure of the effective cost of taxation on investment began with the work of Auerbach (1979), which built a theoretical model where the present value of the investment income flow should equal the cost of capital in order to determine the level of investment.

King and Fullerton (1984) built a new theoretical model and developed the EMTR as a measure of the impact of effective marginal tax rates on investment. In their paper, they applied the EMTR only to the United States, the United Kingdom, Sweden and Germany.

The idea of effective marginal rates on investment gained popularity and got international boost with Alworth (1988), Keen (1991) and OECD (1991), which has incorporated this indicator in its comparative analyzes of taxation between its member countries.

The EMTR constitutes a tool to analyze the impact of the current tax system on the income stream from an investment. The EMTR can be used for calculating the impact of taxation on the level of investment.

Devereux and Griffith (1998) introduced another indicator involving effective tax rates, called the EATR. This new approach measures the effective average tax rate, and estimates the impact of taxation on an investment that earns a given pre-tax rate of return. Thus, the EATR is believed to be a useful tool for investment location decisions, since it provides a complementary view to the EMTR.

Later, Devereux and Griffith (2003) established a theoretical link between the EMTR and the EATR. Their model innovated by incorporating the net present value of depreciation deductions and thus allowing the forward-looking calculation of EATR. Their model was applied to the case of the UK and the US: a EATR time series was built and the location decision of a firm's new industrial plant was simulated to choose the between France, Germany and the UK.

Lorentz (2008) applied both indicators in a broad analysis of the taxation of corporate income in the OECD countries between 1982 and 2007. In that period the nominal rates declined, but the tax basis increased, which resulted in a relative stability 
of revenues. Both the EATR as the EMTR presented a downward trend during the period, although lower than the decrease in the statutory rates. In the average, the EMTR fell from $34 \%$ to $22 \%$ and the EATR was reduced from $37 \%$ to $24 \%$.

Klemm (2008) extended the model by Devereux and Griffith (2003) to consider the possibility of fixed investment. Originally, the model predicted that the increase in capital stock would occur in one period, i.e., the cost of capital was calculated on the basis of a one period perturbation in the stock of capital. In Klemm's revised version, the capital increase becomes permanent. The author argues that the new model is more appropriate for the analysis of long-term investments. But he also points out that the present value calculation procedure for deduction on depreciation in the model of Devereux and Griffith (2003) attenuates the differences between the two models.

Botman, Klemm and Baqir (2008) applied the model introduced by Kleem (2008) for a number of Southeast Asian countries such as the Philippines, Laos, Cambodia, Malaysia, Indonesia, Vietnam and Thailand.

Almeida (2004) and Almeida and Paes (2013) calculated the EMTR to Brazil by using the King and Fullerton methodology (1984). In the former case, the author estimated effective marginal tax rates for Brazil in 2004, including investments in machinery and equipment, buildings and inventories, which could be financed by retained earnings, new shares or debt. In the latter, the authors managed to update Almdeida (2004) for 2012 datasets and to include the impact of interest on net equity in the calculation of effective rates.

Some studies have calculated the EMTR and the EATR to several countries. For example, the Institute for Fiscal Studies - IFS (1997) estimated the EMTR for investment in buildings, machinery and inventories funded by retained earnings, new equity and debt, for a group of 10 OECD countries. Devereux et al. (2002) repeated the exercise for 19 OECD countries and the IFS (2010) updated the numbers of its 1997 study. Polito (2010) calculated the EMTR for the United Kingdom and the United States related to investments in plants and machinery with funding made by issuing shares or debt. Finally, Bilicka and Devereux (2012) published a ranking of the EMTR and the EATR for OECD and G20 countries.

Although widespread, the use of EMTR and EATR as analytical tools for tax policy is not free of criticism. The main issue is that the effective tax rate indicators do not deal with all the complexity existing in modern tax systems, such as accelerated depreciation rules, treatment of tax losses, special regimes, tax planning and tax evasion. However, as stressed by Devereux et al. (2004), both the EMTR and the EATR provide a better picture of the taxation of corporate income than the simple nominal rates and thus they may be useful in the design of tax policy. 
This paper contributes to the literature in several aspects. First, it presents a time series for the EMTR and the EATR for Brazil since 1990. Until now the two Brazilian indicators had only been calculated for 2004 by Almeida (2004) and 2012 by Almeida and Paes (2012) and Bilicka and Devereux (2012). In addition, this paper incorporates the effects of indexation that existed in Brazil until 1996 and by doing that sheds a light on an important peculiarity of Brazil's tax system. A second contribution is to allow comparative analysis among developing countries such as Argentina, India, China, Russia and South Africa. While the literature focuses mainly in OECD countries due to the availability of data, this article builds time series of the EATR and the EMTR for both groups of countries, which allows for the comparison of the tax cost of the investment in Brazil and their peers in the world.

\section{MODEL}

The economic model was built similarly to the one developed by Devereux and Griffith (2003). It allows a microeconomic determination of EATR and EMTR. Consider the value of the firm is given by:

$$
V_{t}=\frac{\frac{\left(1-m^{d}\right)}{(1-c)} D_{t}-(1-z) N_{t}+(1-z) V_{t+1}}{\left(1-m^{i}\right) i_{t}}
$$

In (1), $V_{t}$ is the firm's value at time $t ; D_{t}$ are dividends paid at time $t ; N_{t}$ is new equity issued at time $t ; i_{t}$ is the nominal interest rate; $m^{i}$ is the personal tax rate on interest income; $m^{d}$ is the personal tax rate on dividends; $c$ is the rate of tax credit granted for dividends; and $z$ is the personal tax rate on capital gain.

By simplifying the expression for the value of the firm the following is obtained:

$$
\begin{gathered}
V_{t}=\frac{\gamma D_{t}-N_{t}+V_{t+1}}{1+\rho} \\
\text { In }(2), \gamma=\frac{\left(1-m^{d}\right)}{(1-c)(1-z)}, \rho=\frac{\left(1-m^{i}\right)}{(1-z)} i_{t} \text { and } \theta=\left[1+i_{t}(1-\tau)\right] .
\end{gathered}
$$

Dividends may be expressed as:

$$
D_{t}=Q_{t}(1-\tau)-I_{t}+B_{t}-\theta B_{t-1}+\tau \varphi\left(I_{t}+K_{t-1}\right)+N_{t}
$$

In the above expression, $Q_{t}=Q\left(K_{t-1}\right)$ is the product of the economy at time $t$ and it only depends of the capital from the previous period; $I_{t}$ is the investment in time $t ; B_{t}$ 
is a one period debt of the firm issued at time $t$; $\tau$ is the corporate tax rate; and $\varphi$ is the rate at which capital expenditure can be offset against tax.

The EMTR measures the rising cost of capital due to the corporate income tax. To calculate the cost of capital, one must consider a disturbance in the capital stock at time $t$. Investment increases for one unit in period $t$ and decreases in the following period $t+1$, making capital rise for one unit in $t$ and returns to its previous value in other periods. Thus, the net present value for the shareholder of this disturbance in $t$, $R$, is equal to the change in market value of the firm.

$$
R=\frac{d V_{t}}{d K_{t}}=\sum_{s=0}^{\infty}\left\{\frac{\gamma d D_{t+s}-d N_{t+s}}{(1+\rho)^{s}}\right\}
$$

By setting the economic profit to zero at the margin, the expression $\frac{d V_{t}}{d K_{t}}=0$ defines the cost of capital and allows finding the optimal capital stock at time $t$.

The investment increases by $d I_{t}=1$ and decreases in the following period by $d I_{t+1}=-(1-\delta)(1-\pi)$, where $\delta$ is the one period depreciation rate and $\pi$ is the inflation rate. The addition of capital increases real output in $t+1$ by $d Q_{t+1}=(p+\delta)$, where $p$ is the real financial return on investment. The nominal product increases by $d Q_{t+1}(1+\pi)=(p+\delta)(1+\pi)$.

The disturbance in the capital stock affects the dividends:

$$
d D_{t}=d Q_{t}(1-\tau)-d I_{t}+d B_{t}-\theta d B_{t-1}+\tau \varphi\left(d I_{t}+d K_{t-1}\right)+d N_{t}
$$

Only the hypothesis that the new investment will be entirely financed by means of retained earnings ${ }^{2}$ will be considered. In this case, the return on investment will be distributed as dividends, and it is determined by:

$$
\begin{aligned}
R^{R E}=d V_{t}= & \gamma\left[d Q_{t}(1-\tau)-(1-\tau \varphi) d I_{t}+\tau \varphi d K_{t-1}\right] \\
& +\frac{\gamma}{(1+\rho)}\left[d Q_{t}(1-\tau)-(1-\tau \varphi) d I_{t+1}+\tau \varphi d K_{t}\right]
\end{aligned}
$$

By substituting the derivatives in the previous equation, the following is obtained:

$$
R^{R E}=-\gamma(1-\tau \varphi)+\frac{\gamma}{(1+\rho)}[(p+\delta)(1+\pi)(1-\tau)+(1-\delta)(1+\pi)(1-\tau \varphi)]
$$

\footnotetext{
2 Other usual financing possibilities in the literature are debt and the issuance of new equities. For simplicity, it was chosen to work only with retained earnings.
} 
By setting $R^{R E}=0$, as a measure of the cost of capital, the marginal financial rate of return, $\tilde{p}$, is found:

$$
\tilde{p}=\frac{(1-\tau \varphi)}{(1+\pi)(1-\tau)}[(\rho-\pi)+\delta(1+\pi)]
$$

The ETMR can be obtained as the difference between the marginal rate of return of the investment and the real interest rate, as in (9):

$$
\operatorname{EMTR} \quad \frac{(\tilde{p}-r)}{\tilde{p}}
$$

By replacing values and assuming that there is no taxation on interest and capital gains $\left(m^{i}=z=0\right)$, the following expression for the EMTR in obtained in case of retained earnings:

$$
E M T R^{R E}=\frac{(r+\delta) \tau(1-\varphi)}{(r+\delta)(1-\tau \varphi)-\delta(1-\tau)}
$$

In the case of the EATR, the first step is to find the present value of the net investment for shareholders in the absence of taxation. Based on (7):

$$
R^{* R E}=-\gamma+\frac{\gamma}{(1+\rho)}[(p+\delta)(1+\pi)+(1-\delta)(1+\pi)]
$$

In this case $\gamma=1$ and $\rho=i$. Then,

$$
R^{* R E} \quad \frac{p-r}{1+r}
$$

The EATR can be calculated by the proportional difference between the return of an investment with and without taxes. However, to obtain a rate that represents this indicator, one need to normalize this difference. An alternative is to scale the difference by the net present value of the pre-tax income stream, net of depreciation, $\frac{p}{1+r}$.

Thus, the EATR is defined by:

$$
E A T R^{R E}=\frac{R^{* R E}-R^{R E}}{p / 1+r}
$$


Admitting that there is no tax on the shareholder level $\left(m^{d}=z=m^{i}=c=0\right)$, we obtain the following expression for the EATR:

$$
E A T R^{R E}=\tau\left[1-\frac{r \varphi-\delta(1-\varphi)}{p}\right]
$$

We still have to find the value of $\varphi$, which represents the Net Present Value of depreciation allowances (NPV).

In general, the tax legislation accepts two different methods for calculating depreciation. The first, known as straight-line depreciation, states that an asset may be depreciated at a constant rate. A second possibility is the use of declining balance, which allows higher depreciation rates at the beginning of the life-time of an asset.

In both cases, the value of $\varphi$ can be calculated using the following formulas:

Straight-Line Depreciation

$$
\varphi=\delta \frac{(1+\rho)}{\rho}\left[1-\left(\frac{1}{1+\rho}\right)^{\frac{1}{\delta}}\right]
$$$$
\varphi=\delta \frac{(1+\rho)}{(\rho+\delta)}
$$

Each country determines the depreciation method that is acceptable: straight-line, declining balance or both.

\section{RESULTS AND DISCUSSION}

The model has been applied to a set of countries in order to study the evolution of these indicators. All data related to depreciation and tax rates have been taken from the Centre for Business Taxation at Oxford University ${ }^{3}$. Inflation data have been obtained at the International Monetary Fund International Financial Statistics online database ${ }^{4}$. The IMF data covers varied countries and years, depending on each case (in brackets in the footnote $)^{5}$.

3 https://www.sbs.ox.ac.uk/faculty-research/tax/publications/data.

4 http://data.imf.org/?sk=5DABAFF2-C5AD-4D27-A175-1253419C02D1\&ss=1390030341854.

5 Argentina (1990); Australia (1982); Austria (1981); Belgium (1983); Brazil (1990); Canada (1981); Switzerland (1983); Chile (1996); China (1991); Czech Republic (1991); Germany (1979); Denmark (1986); Spain (1983); Finland (1979); France (1983), UK (1985); Greece (1983); Hungary (1991); Indonesia (1990); India (1990); Ireland (1983); Iceland (1992); Israel (1993); Italy (1983); Japan (1983); South Ko- 
In the case of Brazil, an adjustment is needed to calculate the present value of depreciation for the period before 1996, since the Brazilian law allowed the use of monetary restatement on the depreciation values. As the country's tax law only accepts linear depreciation, the $\varphi$ calculation formula for the 1990-1995 period has been changed to:

Linear depreciation Brazil (1990-1995) $\quad \varphi=\delta \frac{(1+\rho)}{\rho-c . m .}\left[1-\left(\frac{1+c . m .}{1+\rho}\right)^{\frac{1}{\delta}}\right]$

The monetary restatement (c.m.) has been calculated by using data extracted from the Table for Updating the Cost of Assets and Rights on the website of the Federal Revenue of Brazil (RFB), considering the annual value measured in December of each year ${ }^{6}$.

In all the calculations of the EMTR ahead, as is standard in this literature, it has been assumed that the investment is made in machinery and equipment with real interest rate of $5 \%$.

Figure 1 shows the EMTR results for Brazil. The calculations have been made based on the equations (10) and (17) for the period 1990-1995 and on (10) and (15) for the period from 1996 on.

Figure 1 - EMTR, Brazil 1990-2014

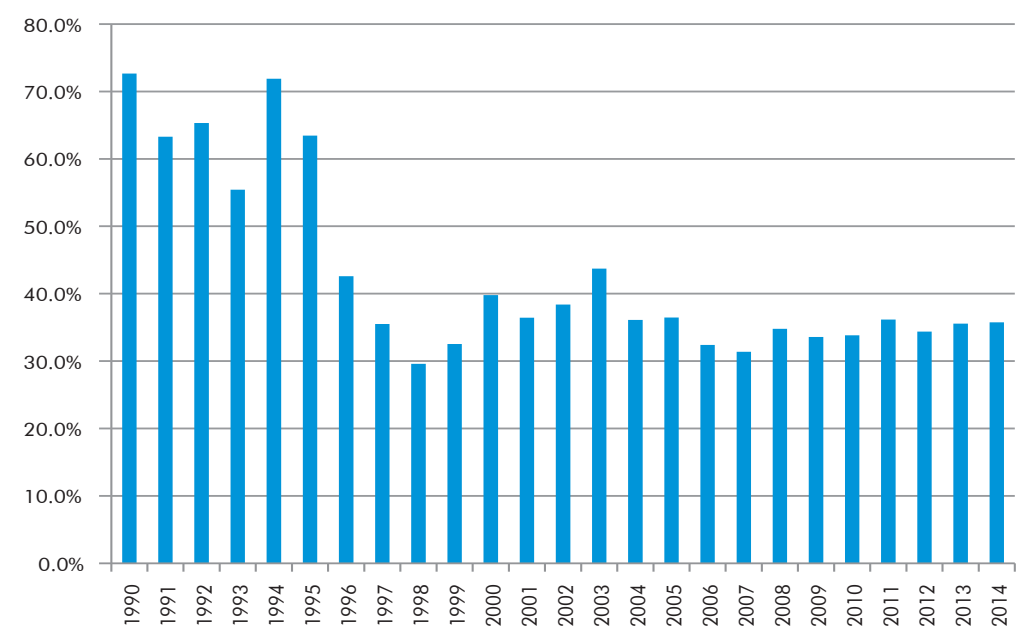

Source: Author's elaboration.

rea (1996); Luxembourg (1991); Mexico (1995); Holland (1983); Norway (1983); New Zealand (1991); Poland (1992); Portugal (1983); Russia (1993); Saudi Arabia (2001); Slovakia (1991); Slovenia (1995); Sweden (1983); Turkey (1991); USA (1983); South Africa (1996).

6 http://www.receita.fazenda.gov.br/Aliquotas/TabAtuBensDir.htm 
The EMTR is very high until 1996 with marginal rates exceeding 50\%. There are two main reasons for that. First, the rate of corporate income taxation in the country was $54 \%$ until 1993, then dropped to $49 \%$ in 1994 and to $46 \%$ in 1995 . A second reason is the hyperinflation of the period, which would eventually erode depreciation, despite the indexation allowed at the time. The combination of high tax rates with huge inflation results in high marginal tax rates on investment in the country.

Inflation in Brazil was substantially reduced from 1996 on in the time series. The stabilization of the economy affected both factors. The corporate income tax rates declined to $32.4 \%$ in 1996, 33\% between 1996 and 1998, and rose to 37\% in 1999 and $34 \%$ since 2000 . Inflation was also substantially reduced and this allowed the present value of depreciation to increase, even with the end of the monetary restatement in 1996. The Brazilian EMTR, then, stabilized at around 36\%, a level slightly above the corporate tax rate $^{7}$.

A comparison of the values of the Brazilian EMTR with that of other LatinAmerican countries and also with the average of OECD countries provides a better picture of the comparative impact of the Brazilian taxation on the return on investment.

Figure 2 - EMTR for Argentina, Brazil, Chile, México e OCDE, 1990-2014

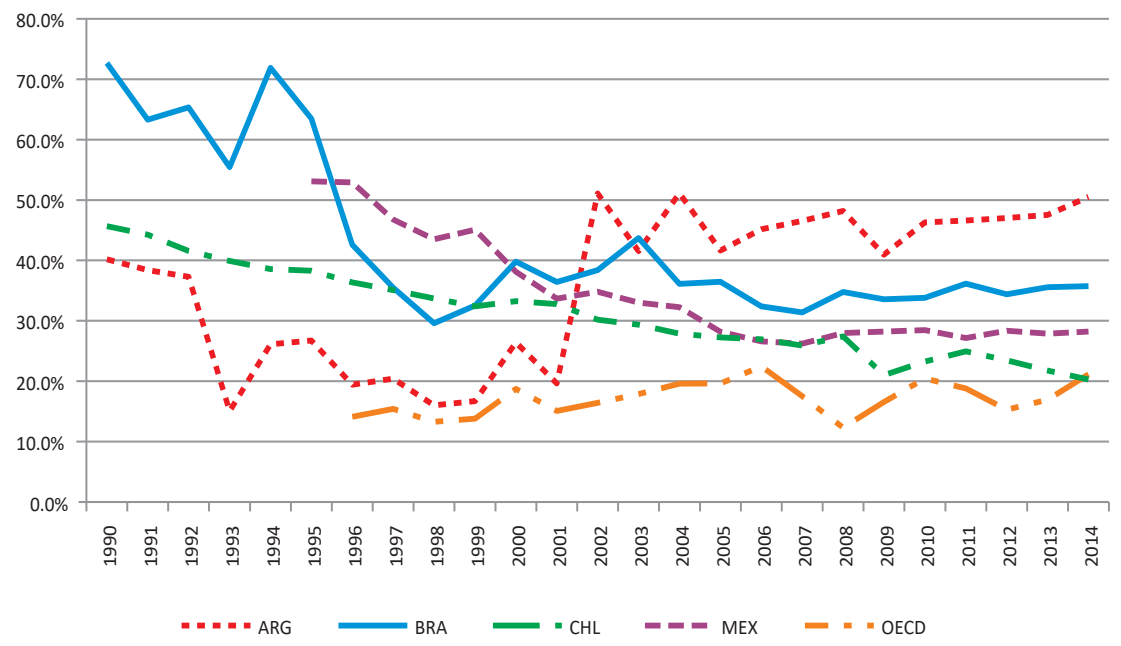

Source: Authors' elaboration.

7 The nominal tax rate in 2014 was $34 \%$, a result of the sum of the rate of $9 \%$ social contribution on net income and $25 \%$ of Corporate Income Tax. 
During the period of hyperinflation and high corporate income tax rates, the Brazilian EMTR was far higher than its Latin American neighbors' and the average for OECD countries. With the stabilization of the economy and reduced tax rates, the country witnessed a progressive decline in EMTR, which eventually stabilized at a relatively high level. The Brazilian EMTR is second only to Argentina, but it is well above that of Chile, Mexico and OECD. The graph shows the gradual and steady decline of the EMTR that developed countries promoted by means of reductions in statutory rates. While the marginal effective tax rate on investment in Brazil is close to $35 \%$, the average rate of OECD countries is about $20 \%$.

Figures 3 ahead compares the evolution of the EMTR within the BRICS.

Figure 3 - EMTR within BRICS, 1990-2014

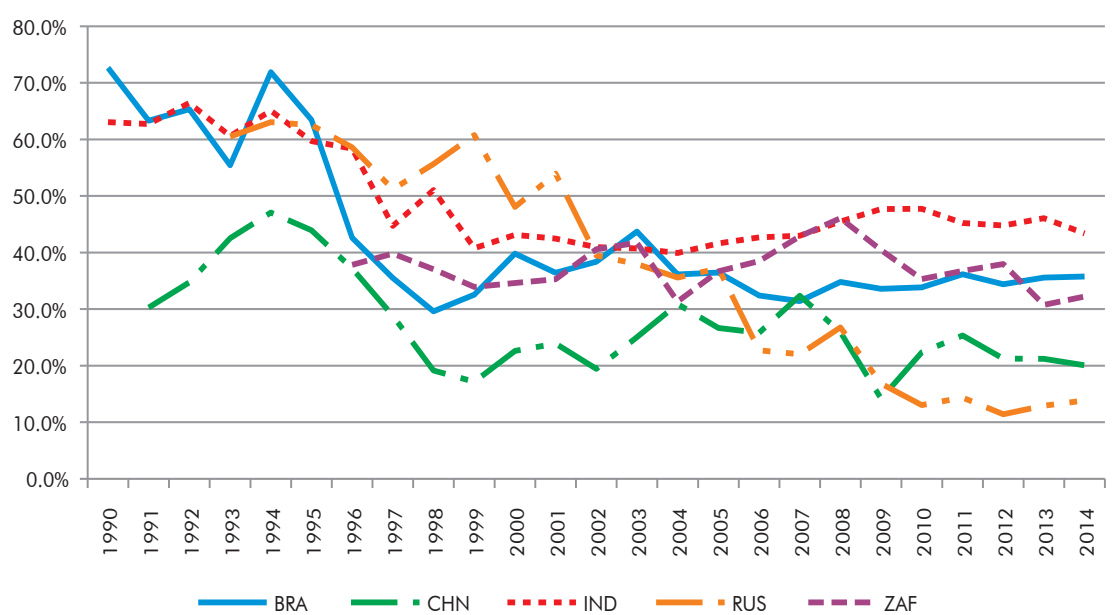

Source: Author's elaboration.

Within the group of major developing nations, Brazil also shows a comparatively high tax on investment. However, the trajectories show that soon after the stabilization of Brazil's economy in 1996, the country had one of the lowest EMTR in the block, higher only than that of China. Over time, Russia sharply reduced their nominal rates, from 35\% in 1999 to $20 \%$ from 2009 and more recently, South Africa, has also promoted cuts in taxation with declining rates of corporate income tax from $34.55 \%$ in 2012 to $28 \%$ in 2013 and 2014. Brazil is currently the second country with the highest EMTR in the BRICS, second only to India.

As for the EATR, it is important to remember that this indicator is suitable for the making investment location decisions among different countries, since it provides a measure of the average impact of taxation on the return on investment. 
Once again, the results have been calculated assuming an investment in machinery and equipment with real interest of $5 \%$. It is assumed that the real financial return expected from the investment will be $10 \%$.

Figure 4 shows the EATR results for Brazil. As in the EMTR case, it was necessary to incorporate the monetary restatement until 1996. Therefore, the calculations have been made based on the equations (14) and (17) for the period from 1990 to 1995 and on (14) and (15) for the period ranging from 1996 on.

Results show that the EATR was also influenced by the high inflation and the high tax rates present in Brazil until 1995. Since the stabilization of the economy in 1996 and the fall in corporate income tax rates, the EATR has remained 35.4\%, a level slightly lower than the EMTR, but above the current tax rate of $34 \%$.

Figure 4 - EATR, Brazil, 1990-2014

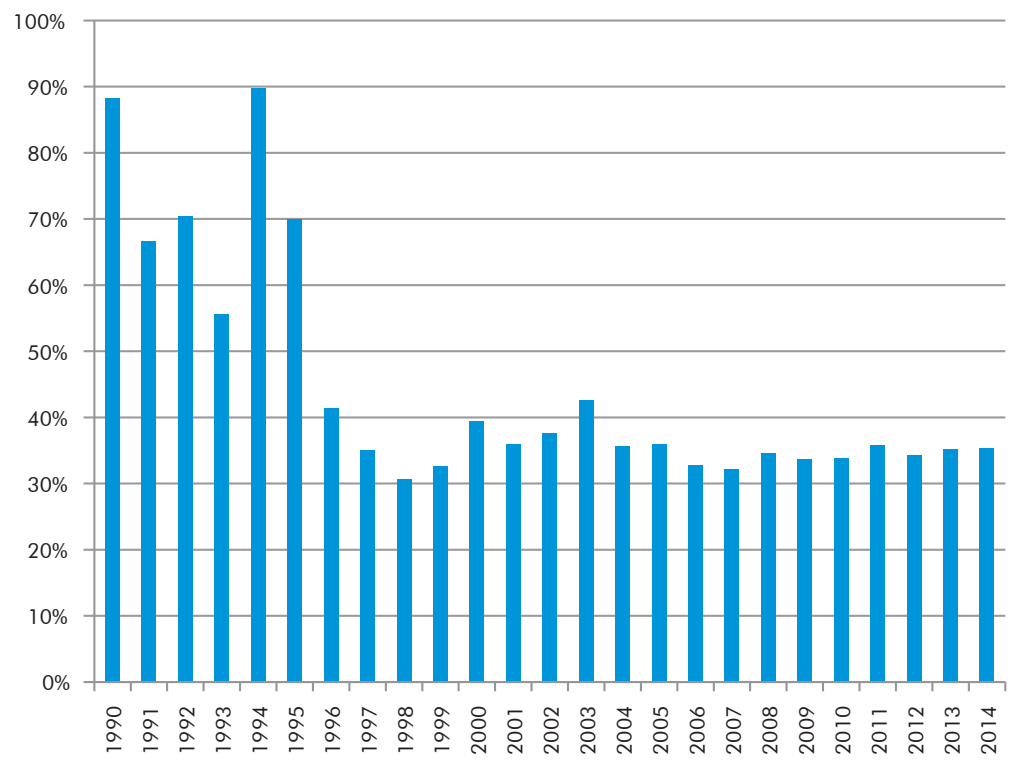

Source: Author's elaboration.

The comparison of Brazil's rates to those of the major economies of Latin America and the average for developed countries (OECD) helps to understand the taxation on investment in a comparative perspective. Figure 5 ahead shows the results. 


\section{Figure 5 - Comparative EATR for Argentina, Brazil, Chile, México and OECD countries, 1990-2014}

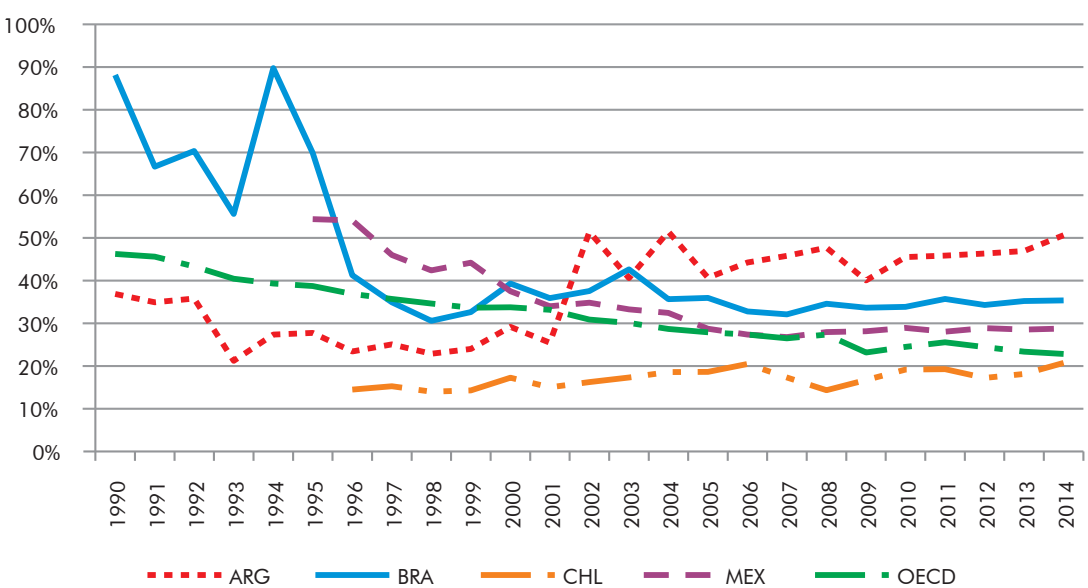

Source: Authors' elaboration.

The behavior of the EATR is clearly very similar to that of the EMTR. Brazil is almost always the second country with the highest EATR level. Noteworthy is the Chilean indicator, whose values are the lowest along the whole series, ranging from $15 \%$ to $20 \%$ between 1996 and 2014, largely due to reduced statutory rates in the country.

The following figure compares the trajectories of the EATR within the BRICS.

Figure 6 - EATR, BRICS, 1990-2014

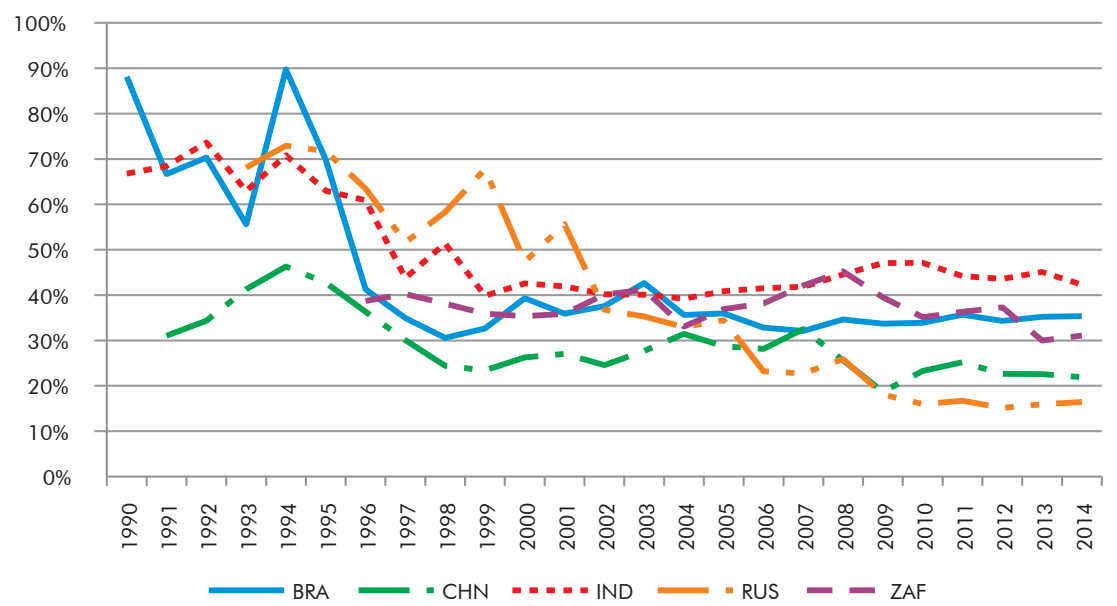

Source: Author's elaboration. 
The results are again similar to that obtained with the EMTR, with only minor differences. For example, China's EMTR was $20 \%$ and the EATR was calculated at $22 \%$. India's EMTR was calculated at $44 \%$, while the EATR was $42 \%$. Compared to other BRICS countries Brazil also showed a relatively high rate, 35\%, second only to India. Interestingly, both countries have the same nominal rate, but India's inflation is higher and the depreciation method adopted in that country is also different - India adopts declining balance depreciation and Brazil straight-line depreciation.

It should be noted the reduction of corporate income tax rates that occurred in the BRICS countries from 2007 on has not been followed by Brazil and India. For example, China reduced it from 33\% to 25\% since 2007; in South Africa it feel from $34.5 \%$ to 28\% from 2012 on; and in Russia from 24\% to 20\% from 2008.

The framework suggested by the indicators is that Brazil may face difficulties in attracting investment. The high EATR puts the country in an unfavorable condition in the competition for attracting investment. And yet, the high EMTR also suggests that even if the country is chosen, the investment size may be lower.

But some of those results must be put into perspective. Taxation is only one part of the complex decision-making process in the allocation of investments. Several assumptions about the structure and financing of the investment must be made and some real world features are not dealt with by the model. For example, the existence of tax benefits such as accelerated depreciation, reduced tax base, loss compensation and incentives for research and development are not considered.

Still, the EMTR and the EATR provide a better picture of the taxation of corporate income than the simple nominal rates. Both indicators are important for providing an average indicative of the size of taxation a firm would actually face in the country. In Brazil, the combination of high rates and still high inflation ends up making it more difficult to attract investments.

\section{CONCLUSION}

This paper has investigated the role of taxation of corporate income on investment by using an economic model to calculate two indicators of effective tax rates - the EMTR and the EATR.

It has been observed that the effective tax rates on investment in Brazil are high, despite their decreased since the stabilization of the currency in the mid-1990s. Two reasons can be pointed out for this reduction. First, the rate of corporate income taxation dropped from 54\% in 1993 to $34 \%$ from 2001. Second, the control of inflation increased the present value of depreciation. 
Even with reduced effective tax rates, both the EMTR and the EATR still remain relatively high in Brazil. They are higher compared to the rates of the average of the OECD countries and that of relevant developing countries such as Mexico, Chile, Russia, China and South Africa. As highlighted before, high effective rates could put Brazil in an unfavorable condition in the competition for attracting investments.

The reduction of corporate income tax rates seems to be an appropriate measure for Brazil. The country has very high rates that do not result in higher revenues. Lower rates, accompanied by the suppression of tax benefits, is expected to reduce the opportunities for tax avoidance and can help the country to boost its competitiveness in terms of investment attraction.

A second improvement measure for the country could be a revision of the depreciation rules that makes them friendlier to investment. Due to technological developments, machinery and equipment tend to depreciate faster and faster, and it would be important to adapt the tax legislation in Brazil to this trend.

\section{REFERENCES}

ALMEIDA, A. A tributação dos lucros e o retorno ao investimento no Brasil. Menção Honrosa IX Prêmio Tesouro Nacional, Brasília-DF, 2004.

ALMEIDA, A.; PAES, N. The influence of interest on net equity and interest rates on tax neutrality - a case study of the Brazilian corporate taxation. EconomiA, v. 14, n. 3-4, p. 185198, 2013.

ALWORTH, J. The finance, investment and taxation decision of multinationals. New York: Basil Blackwell, 1988.

AUERBACH, A.J. Wealth maximization and the cost of capital. Quarterly Journal of Economics, v. 21, n. 1, p. 107-127, 1979.

BILICKA, K., AND DEVEREUX, M. CBT Corporate Tax Ranking 2012. Oxford: Oxford University Centre for Business Taxation, 2012.

BOTMAN, D.; KLEMM, A.; BAQIR, R. Investment incentives and effective tax rates in the Philippines: a comparison with neighboring countries. IMF Working Paper, n. 08/207, 2008.

CNI - CONFEDERAÇÃO NACIONAL DA INDÚSTRIA. O custo tributário dos investimentos: as desvantagens do Brasil e as ações para mudar. Brasília: CNI, 2014

DEVEREUX, M., GRIFFITH, R. Taxes and the location of production: evidence from a panel of US multinationals. Journal of Public Economics, v. 68, n. 3, p. 335-367, 1998.

DEVEREUX, M.; GRIFFITH, R. Evaluating Tax Policy for Location Decisions. International Tax and Public Finance, v. 10, n. 2, p. 107-26, 2003.

DEVEREUX, M. "Measuring taxes on income from capital". In: SORENSEN, P. B. (Ed.). Measuring the tax burden on capital and labor. Cambridge, MA: MIT Press, 2004, p. 35-71. 
DEVEREUX, M.; KLEMM, A. "Measuring Taxes on Income from Capital: Evidence from the United Kingdom". In: SORENSEN, P. B. (Ed.). Measuring the tax burden on capital and labor. Cambridge, MA: MIT Press, 2004, p. 73-91.

DEVEREUX, M. The Impact of taxation on the location of capital, firms and profit: a survey of empirical evidence. Working Paper, Oxford University Centre for Business Taxation, n. 07/02, 2006.

IFS - INSTITUTE FOR FISCAL STUDIES. Taxing profits in a changing world. London: Institute for Fiscal Studies, 1997.

IFS - INSTITUTE FOR FISCAL STUDIES. Mirrlees review: dimensions of tax design. London: Institute for Fiscal Studies, 2010.

KEEN, M.J. Corporation tax, foreign direct investment and the single market. Essex: University of Essex, 1991.

KLEMM, A. Effective average tax rates for permanent investment. IMF Working Paper, n. 08/56, 2008.

KING, M.A. and Fullerton, D. The taxation of income from capital. Chicago: University of Chicago Press, 1984.

LORETZ, S. Corporation taxation in OECD in a wider context. Oxford Review of Economic Policy, v. 24, n. 4, p. 639-660, 2008.

NICODEME, G. Computing effective corporate tax rates: comparisons and results. Economic Paper, Directorate General for Economic and Financial Affairs, European Commission, n. 153, 2001.

OECD - ORGANISATION FOR ECONOMIC COOPERATION AND DEVELOPMENT. OECD Tax Database. OECD [Online], s/d. Disponível em: < http://www.oecd.org/tax/taxpolicy/tax-database.htm\#C_CorporateCaptial>. Acesso em 07 jun. 2017.

OECD - ORGANISATION FOR ECONOMIC COOPERATION AND DEVELOPMENT. Taxing profits in a global economy. Paris: OECD, 1991.

OECD - ORGANISATION FOR ECONOMIC COOPERATION AND DEVELOPMENT. Tax ratios: a critical survey. OECD Tax Policy Studies, n. 5, 2001.

POLITO, V. Up or down? Capital income taxation in the United States and the United Kingdom. CES-Ifo Working Paper, n. 3260, 2010. 